Peshawar Journal of Psychology and Behavioral Sciences, 2015, Vol. 1, No. 1, 1-13

\title{
Job Satisfaction Among Public and Private School Teachers
}

\author{
Maher Bano ${ }^{1}$, \\ Preston University Peshawar
}

\author{
Syeda Kaniz Fatima Haider ${ }^{2}$ \\ University of Peshawar \\ and \\ Alay Ahmad ${ }^{3}$ \\ Preston University Peshawar
}

This paper compares job satisfaction of private and public school teachers in Peshawar. Sample comprised of sixty $(\mathrm{N}=60)$ teachers of both genders ranging in age from 25-50 years. Thirty $(n=30)$ were public school teachers including fifteen $(\mathrm{n}=15$ male) and fifteen $(n=15)$ female teachers, thirty $(n=30)$ private school teachers they included fifteen $(n=15)$ male and fifteen $(n=15)$ female teachers. The data was collected through non-probability sampling technique from Mardan city of Khyber Pakhtunkhwa. A questionnaire was constructed for the purpose of measuring Job satisfaction for teachers. The alpha reliability coefficient was significantly high, thus ensuring the reliability of the scale. The results showed that public teachers are more satisfied with their job as compared to teachers working in private schools. It was further revealed that there was no significant difference between male and female teachers working in public schools and private schools.

Keywords. Teachers, Job Satisfaction, Public school, Private school

Job satisfaction is the person's positive perception towards their job it's environment and activities associated with job. It is a relatively new phenomenon as in the past people used to follow and adapt their

\footnotetext{
${ }^{1}$ Professor, Department of Psychology, Preston University Peshawar

2Professor, Human Development Department, College of Home Economics, University of Peshawar

3Professor, Department of Psychology, Preston University Peshawar
} 
ancestral profession. With advancement of science and technology people have learned to opt for professions. There is abundance of work available on this topic in technological advanced countries (Zembylas \& Papanastasiou, 2006) but little attention is paid to this issue in Pakistan and more specifically in Khyber Pakhtunkhwa.

Efforts to improve the education system and school performance will never be achieved ignoring job satisfaction of the teachers. Motivated employees render quality services to the organization and employer efficiently (Mbua, 2003). This indicates that satisfied and motivated teachers are most likely to have positive influence on the students' general behavior and their interest in their learning and academic activities. However the unmotivated and unsatisfied teachers may have negative impact on performance and behavior of students. Educational leaders and administrators/ managers have to pay special attention to the phenomena of motivation and job satisfaction.

Teachers are a crucial element of education. Teachers are more concern with future of student. They are just like model for them so; their job should be well and full of facilities. So, then they will enjoy their job and will be satisfied. To encourage efficient teaching learning relation, satisfaction of the teachers to their job and interest is very important. Because unsatisfied teachers can't give the level of the quality that is required for a successful and developed nation (Van-zyl and Pieterson 1999).

Teachers are satisfied in schools with better economic resources in large school, in school where there are more opportunities for professional advancement and in schools where organizational climate support teacher's collaboration. Young teachers male and female with great human capital are less satisfied (Charney 1998).

A study conducted by Rodgers, Jenkinson and Chapman (1990) investigated the correlation of job satisfaction among public and private Jamaicans elementary school teachers. Results indicated that the qualities of school working conditions were significantly related to satisfaction for both public and private teachers. Schools prestige was also significant predictor for public schools teacher or organizational structure predicted job satisfaction for private school teachers.

Job satisfaction explains how gratified, relaxed and happy an individual is with his or her job. Job satisfaction has a recently become 
popular and is the issue of many researchers in the field of social sciences. In past the occupations of the parents were the occupation of their children, and the families were known for their occupations. Number of factors can influence the job satisfaction of an individual; some of these factors involve the amount of salary and perks and privileges, the quality of the working conditions, promotion opportunities and perceived fairness of the promotion procedure within an organization, leadership and social relationships, and the job itself (the interest, clear job descriptions, and variety of duties involved). Job satisfaction and motivation are two separate terms but there is an association between the two concepts. Besides motivations there are variety of factors that influence job satisfaction they include, organizational culture and management style, involvement of employees, autonomy in the employees and delegation of responsibilities to the employees and empowered workers. Job satisfaction is a very important characteristic, which is regularly measured by organizations.

Job satisfaction is commonly measured through structured questionnaires using rating scales. The employees report their perception about their organization where they serve. Questionnaire may include items related to personal opinion of their liking or disliking their job, their colleagues and their relationship with the colleagues, their salary, appropriate tasks assigned, support of employer, opportunities for fair promotion, promotional opportunities, support provided by the employer, and the work itself. Job satisfaction has been defined as a positive emotional state resulting from the one's job appraisal; an affective response to one's job; and one's positive attitude towards his/her job.

\section{Theories of Job satisfaction}

\section{Edwin locks's Range of Affect Theory}

Edwin locks's Range of Affect Theory (1976) is among the most famous job satisfaction theories. This theory states that job satisfaction is basically focused on the discrepancy between what one has in a job and what one wants in a job. This theory further focus on the level of value one gives to the duties at work (the amount of freedom in a position) 
effects the level of satisfaction or dissatisfaction due to attainment of their needs according to their expectations. The When a person values certain features of a job, his/her satisfaction is significantly influenced both positively and negatively by their expectations being met or by their expectation not being met in the organization where they serve, compared to those who do not value that facet.

For example if Employee $\mathrm{X}$ give importance to the fair promotion and Employee $\mathrm{Y}$ is indifferent towards fair promotion in the workplace, the Employee $\mathrm{X}$ will be more satisfied in the workplace that offers opportunities for fair promotion and may be less satisfied in the absence of fair chances of promotion at workplace, than the Employee $Y$ who is indifferent towards fair promotion opportunities. This theory also uncovers the role of too much high motivation or strong desire of employee for a particular facet may cause stronger negative feelings in the form of severe dissatisfaction.

\section{Dispositional theory}

This theory suggests that individuals have inborn dispositions for inclination towards inclinations toward a certain level of job satisfaction, regardless of the type of one's job. This theory became a notable explanation of job satisfaction in light of support that job satisfaction tends to be stable over time and across careers and jobs. Research also suggests that identical twins have similar levels of job satisfaction. The Core Self-evaluations Model (Timothy A. Judge, 1998) is an important model that narrowed the scope of the Dispositional Theory. The Core Self-evaluations Model (Timothy A. Judge, et al., 1998)suggests that there are four Core Self-evaluations that determine one's disposition towards job satisfaction: general self-efficacy, self-esteem, neuroticism, and locus of control. According to this model, higher level of self-esteem and general self-efficacy plays significant role in job satisfaction. In other words higher the self-esteem and general self-efficacy higher will be job satisfaction. This theory further illustrates the significance of internal locus of control, that states higher the internal locus of control higher will be the job satisfaction, because it is believed that internal

locus of control means one's control over herlhis life. And lower the 
neuroticism higher will be the job satisfaction among employees in the workplace.

\section{Hartzberg's two factor theory}

Hartzberg's two factory theory also called as Motivator Hygiene Theory. This theory explained the significance of satisfaction and motivation in the workplace. It sates that motivation and hygiene factors are two important factors that lead to satisfaction and dissatisfaction. Motivation is a goal directed behavior that drives people to perform their duties, thus further lead them to feeling of satisfaction after accomplishment of task, recognition, and opportunities etc. These motivating factors are considered to be intrinsic to the job, or the work carried out. However pay, organizational culture and environment, supervision etc are considered to be hygiene factor. Despite of the popularity of Hertzberg's model and the research and the researcher it has stimulated have not been able to empirically prove the model. The major criticism for this model was that it is not clear how Hartzberg measured motivation and personal hygiene factors. The major critic of the study was Hackman and Oldham (1980) who later proposed their own theory of job characteristic model.

\section{Job Characteristics Model}

Hackman \&Oldham (1980) proposed the job characteristics model, which is generally accepted as an outline for investigating specific job characteristics and their impacts on job outcomes, such as job satisfaction. The model suggests five main job characteristics they include autonomy, skills, task significance and feedback, which influence three important psychological states they include experienced responsibility for outcomes, experienced meaningfulness and knowledge of the actual outcomes, in turn influencing work outcomes job satisfaction level of the faculty members measured with the help of five dimensions namely; job, coworkers, pay, supervisor, and promotion.

Information regarding faculty member's age, education, job level, foreign qualification, numbers of years in organization, other sources of income, sex, and marital status have also been obtained. Total 
score obtained by combining the five core job characteristics form a motivating potential score (MPS) for a job, which can be used as an index of how likely a job is to affect an employee's attitudes and behavior.

\section{Motivation for the Study}

Pakistan a country of about 180 million people; with low education growth rate are the factors that needs to be focused and requires special attention. Education is the fundamental right of all the citizens of Pakistan. It is not possible for the government to provide free of cost education to everyone in Public schools. Private schools have been shouldering the responsibility of providing self finance quality education with the supervision of government. Teacher is the most important element in ensuring the quality education in both public and private schools. The quality output of education is not possible if the teachers are not satisfied at their workplace. The aim of the present study was to find the difference between the job satisfaction of the public and private school teachers.

\section{Objectives}

1. To find the difference between job satisfaction of public and private school teacher

2. To investigate role of gender in job satisfaction in public and private school teachers

\section{Hypotheses}

1. Teachers in government owned schools will score high on job satisfaction scale than teachers working in private schools

2. Female teachers will score higher on job satisfaction scale as compared to male teachers 
Method

Sample

Sample comprised of Sixty $(\mathrm{N}=60)$ school teachers, consisted of thirty $(n=30)$ teachers from public school in which fifteen $(n=15)$ were female teachers and fifteen $(n=15)$ were male teachers. The sample included thirty $(\mathrm{n}=30)$ private school teachers which consisted of fifteen $(n=15)$ female teachers and fifteen $(n=15)$ male teachers with the age range of 25-50 years.

\section{Instruments}

\section{Demographic Information}

A questionnaire comprising of demographic information such as age, gender, education etc was used in the data collection

\section{Job Satisfaction Scale}

A job satisfaction scale was developed for the purpose of measuring job satisfaction among teachers. The scale consisted of fifteen (15) items. The alpha reliability coefficient of the scale was 0.87 that shows the high reliability of the scale.

\section{Procedure}

To carry out the research we have taken permission from concerned head of the different schools of Mardan city. It was a comparative study. The research conducted at private and public schools in Mardan city in Pakistan form December (2007) to May (2008). We use random sampling technique for the assignment of subjects to the two groups with equal ratio of male and female. The groups included teachers of public school and teachers of private schools. Demographical data of all subjects of two groups $(\mathrm{N}=60)$ were obtained. In addition, we individually administered questionnaire consisted of fifteen items. After approaching the field, rapport was developed. Before delivering the scale instructions were given to the participants about the questionnaires. 
Repetition was also made when required. In this way data was collected. The research intended to investigate the level of job satisfaction among public and private school teachers.

Table 1

\section{Results}

Difference between Public and Private School Teachers on Job Satisfaction $(\mathrm{N}=60)$

\begin{tabular}{ccccccccc}
\hline $\begin{array}{c}\text { Public School } \\
(\mathrm{n}=30)\end{array}$ & $\begin{array}{c}\text { Private School } \\
(\mathrm{n}=30)\end{array}$ & & & & & \\
\hline $\mathrm{M}$ & $\mathrm{SD}$ & $\mathrm{M}$ & $\mathrm{SD}$ & $\mathrm{t}(58)$ & $\mathrm{p}$ & $\frac{\mathrm{CI} 95 \%}{2}$ & $\begin{array}{c}\text { Cohen's } \\
\mathrm{d}\end{array}$ \\
\hline 64.26 & 6.73 & 61 & 4.77 & 2.16 & 0.03 & 0.24 & 6.27 & 0.55 \\
\hline
\end{tabular}

Note. JS = Job Satisfaction

Table 1 shows the mean, standard deviation and t-value of public and private school teachers on job satisfaction. Public school teachers scored higher on job satisfaction, which means they are more satisfied than private school teachers. The results are significant at $\mathrm{p}<.05$ level.

Table 2

Gender Difference between Public and Private School Teachers on Job Satisfaction $(\mathrm{N}=60)$

\begin{tabular}{|c|c|c|c|c|c|c|c|c|c|}
\hline \multirow[b]{2}{*}{ Variables } & \multicolumn{2}{|c|}{$\begin{array}{c}\text { Male } \\
(\mathrm{n}=15)\end{array}$} & \multicolumn{2}{|c|}{$\begin{array}{l}\text { Female } \\
(n=15)\end{array}$} & \multirow[b]{2}{*}{$\mathrm{t}(28)$} & \multirow[b]{2}{*}{$\mathrm{p}$} & \multicolumn{2}{|c|}{$95 \% \mathrm{CI}$} & \multirow[b]{2}{*}{$\begin{array}{c}\text { Cohen's } \\
\text { D }\end{array}$} \\
\hline & $\mathrm{M}$ & SD & $\mathrm{M}$ & SD & & & $\mathrm{LL}$ & UL & \\
\hline \multicolumn{10}{|c|}{ Public Schools } \\
\hline & 64 & 7.62 & 64.53 & 5.96 & -0.21 & 0.83 & $\overline{5}-64$ & 4.58 & 0.07 \\
\hline \multicolumn{10}{|c|}{ Private Schools } \\
\hline
\end{tabular}

Peshawar Journal of Psychology and Behavioral Sciences, 2015, Vol. 1, No. 1, 1-13 
Table 2 shows mean scores, standard deviation and t-value of male and female public and private school teachers on job satisfaction. Overall females scored higher than male teachers both in public and private schools, but interpretations cannot be drawn as there was no significant difference between the score of male and female teachers at $\mathrm{p}<.05$ level both in public and private schools.

\section{Discussion}

The aim of the study was to find out the job satisfaction level Public and private school teachers both males and females. It was assumed that teachers working in public schools are more satisfied with their job as compare to private school and from table $1(t=2.168, p=0.03)$ the results are significant at $\mathrm{p}<.05$ level and it was supported by findings that teachers working in public schools are more satisfied as compare to private schools teachers. A study was conducted by Crossman and Harris on the job satisfaction related to types of schools. Results indicate that a significant difference in the overall job satisfaction scores of teachers by type of school. Teachers in public school exhibited highest satisfaction while those in foundation school exhibited the lowest. No significant difference in satisfaction was found when the data were analyzed by age, gender and length of service.

It was also assumed that male in public school are more satisfied with their jobs as compare to females in public schools. The results in table $2(\mathrm{t}=.213, \mathrm{p}=.833)$ the results are not significant at. .05 level and it was not supported by findings. So males are less satisfied with their jobs than female. A study conducted by Anthea and long (2005) investigated the issue of job satisfaction and gender. The finding shows that women are significantly happier in work than man. The determinants of job satisfaction for male and woman in this group are significantly different. It is conjectured that this result is due to difference in expectations of work among man and woman. Then it was assumed that females in private schools are less satisfied with their jobs as compare to males in private schools. The results in table $3(\mathrm{t}=1.153, \mathrm{p}=.259)$ shows that there is non-significant difference $(\mathrm{p}>.05)$. So it is not supported that females 
are less satisfied with their jobs as compare to male in private schools teachers. A study conducted by Tasnim and Shamima (2006), this study was conducted to analyze the job satisfaction among the female and male teachers run primary schools in Bangladesh. The prime aim of this study was to find the perception of job satisfaction and identify the factors which affect job satisfaction of female teachers. There was no difference on the job satisfaction level. It was found that both the males and female teachers are less satisfied but the female sections were more dissatisfied than those of the male teachers.

The result findings indicate that overall public school teachers are more satisfied because they can enjoy the facilities of high pay and transport service and free medical services. Whereas teachers of private schools can not enjoy all these feasibilities because they have low pay and more work related burden.

\section{Conclusion}

This research was conducted to find out the level of job satisfaction among males and females teachers working in public and private schools. It was concluded that teachers working in public schools are more satisfied with their jobs as compare to teachers working in private schools. Another conclusion was derived that there is no significant gender difference in job satisfaction of public and private schools teachers.

\section{Summary}

The study was based on the job satisfaction level among male and female teachers. Sample consisted of Sixty subjects of both genders in age from 25-50years from public and private schools of Mardan. In this research was use self-constructed questionnaire of job satisfaction consisted of fifteen items which measured their interest in job and their satisfaction level to doing this job

Random sampling technique was used. There were three hypotheses in this study, which measured the severity and prevalence of job satisfaction level among public and private school teachers. It was assumed that teachers working in public schools are more satisfied jobs 
as compare to private schools and the second hypothesis was that males in public school are more satisfied with their jobs as compare to female in public schools and the third hypothesis was that females in private schools.

Our result showed that public school teachers are more satisfied with their jobs as compare to private school teachers because they enjoyed more facilities in services and private school teachers cannot enjoyed these facilities. It was also assumed males in public school are more satisfied with jobs as compare to females in public school and females in private schools are less satisfied with their jobs as compare to males in private school. The results showed non-significant difference in gender.

\section{References}

Arvey, R. D., Bouchard, T. J., Segal, N. L., \& Abraham, L. M. (1989). Job satisfaction: Environmental and genetic components. Journal of Applied Psychology, 74, 187-192.

Bian, Y. 2002. Chinese social stratification and social mobility. Annual Review of Sociology, 28: 91-116.

Carsten, J. M., \& Spector, P. E. (1987). Unemployment, job satisfaction, and employee turnover: A meta-analytic test of the Muchinsky model. Journal of Applied Psychology

Darling-Hammond, L, Green, J. (1990) Teacher a quality and equality. In P. Kealing\& J.I Goodlad (Eds) Access to knowledge. New York College entrance examination Board

Hacket, r.D., \&Guion, R.M. (1985). A reevaluation of the absenteeismjob satisfaction and relationship. Organizational Behavior \& Human Decision processes

Hackman, J.R., Oldham, G.R. (1980). Work redesign. Reading, MA: Addison-Wesley.

Herzberg F., Mausner, B., \& Synderman, B.B. (1959). The Motivation to Work $\left(2^{\text {nd }}\right.$ ed. $)$. New York: John Wiley \& Sons.

Judge, T. A., Locke, E. A., Durham, C. C., \&Kluger, A. N. (1998). Dispositional effects on job and life satisfaction: The role of core evaluations. Journal of Applied Psychology, 83, 17-34. 
Judge, T.A. and Church, A.H (2000). Job Satisfaction Research and practice. In C.L. Cooper and E.A. Locke (Eds). Industrial and organizational psychology : Linking theory with practice (pp. 166-198). Oxford, UK : Blackwell.

Judge, T.A., \& Watanabe, S. (1993). Another look at the job satisfactionlife satisfaction relationship. Journal of Applied Psychology.

Locke, E. A . (1976). "The nature and causes of job satisfaction." In M. D. Dunnette (Ed.), Handbook of Industrial and Organizational Psychology. (1297-1349). Chicago: Rand McNally, 1976.

Locke, E.A. (1976). The nature and causes of job satisfaction. In M.D. Dunnette (Ed.), Handbook of Industrial \& Organizational Psychology.

Mbua, F. N. (2003). Educational Administration: Theory and Practice. Limbe, South West Province, Cameroon: Design House.

Rodgers-Jenkinson,F.\& Chapman, D.W.(1990). Job Satisfaction of Elementary School Teachers. International Review of Education,36, 299-313

secondary school teachers. South African Journal of Education

Smith, P.C., Kendall, L.M., \& Hulin, C.L.(1969). Measurement of satisfaction in work and retirement. Chicago: Rand Mentally.

Tasnim, S (2006). Job satisfaction among female teachers: A study on primary schools in Bangladesh. M.Phil Thesis. Department of Administration and Organization Theory, University of Bergen, Norway

Van Zyl, E. and C. Pietersen. (1999). An investigation into work stress experienced by a group.

www.Cric.ed.gov/ericwebportal/custom/record/details/detailmini .jsp.nFP

Zembylas, M. \&Papanastasiou, E. C (2006). Sources of teacher job satisfaction and dissatisfaction in Cyprus. $A$ journal of comparative education, 36(2), 229-24. 